\title{
Multimodal modelling of the human brain
}

Citation for published version (APA):

Ziegler, E. (2014). Multimodal modelling of the human brain. [Doctoral Thesis, Maastricht University]. Maastricht University. https://doi.org/10.26481/dis.20141120ez

Document status and date:

Published: 01/01/2014

DOI:

10.26481/dis.20141120ez

Document Version:

Publisher's PDF, also known as Version of record

\section{Please check the document version of this publication:}

- A submitted manuscript is the version of the article upon submission and before peer-review. There can be important differences between the submitted version and the official published version of record.

People interested in the research are advised to contact the author for the final version of the publication, or visit the DOI to the publisher's website.

- The final author version and the galley proof are versions of the publication after peer review.

- The final published version features the final layout of the paper including the volume, issue and page numbers.

Link to publication

\footnotetext{
General rights rights.

- You may freely distribute the URL identifying the publication in the public portal. please follow below link for the End User Agreement:

www.umlib.nl/taverne-license

Take down policy

If you believe that this document breaches copyright please contact us at:

repository@maastrichtuniversity.nl

providing details and we will investigate your claim.
}

Copyright and moral rights for the publications made accessible in the public portal are retained by the authors and/or other copyright owners and it is a condition of accessing publications that users recognise and abide by the legal requirements associated with these

- Users may download and print one copy of any publication from the public portal for the purpose of private study or research.

- You may not further distribute the material or use it for any profit-making activity or commercial gain

If the publication is distributed under the terms of Article $25 \mathrm{fa}$ of the Dutch Copyright Act, indicated by the "Taverne" license above, 


\begin{abstract}
There are many ways to model properties of the brain from magnetic resonance imaging (MRI) data. One acquisition technique, known as diffusion-weighted imaging (DWI), can map the speed and direction of water diffusion within the brain. This work explores the quantitative potential of DWI, in combination with other neuroimaging modalities, for in vivo modelling of the human brain.

Fiber tractography from DWI can be used to construct a wiring diagram of the brain (or connectome) and identify connectivity patterns between regions. To explore the utility of connectome modelling, we constructed brain networks from healthy subjects carrying known genetic variations. Using machine learning, we demonstrated high classification accuracy between subjects with different genotypes using only their connectomes. Next, we tested whether fiber track density images could be used to detect early pathological effects in patients with Parkinson's disease. We found increases in track density in disease-relevant regions of the white matter, including the nigrostriatal pathway, used unbiased whole-brain statistical testing. This result is extremely encouraging, as axonal degeneration within this area is challenging to identify with standard magnetic resonance imaging contrasts.

Finally, a finite element modelling (FEM) approach was developed for solving the electroencephalography (EEG) forward problem. Electrical conductivity tensors were estimated from DWI in order to represent the heterogeneous conductivity profile of the white matter. When tested against the analytical solution, this FEM method proved more reliable than the current state-of-the-art alternative.

Advanced brain modelling from DWI can clearly provide lucrative results. These methods have been open-sourced for use by the community.
\end{abstract}

